\title{
Socio- Economic Factors Influencing the Probability of Market Participation among the Cattle Farmers in Adamawa State, Nigeria

\author{
Mohammed Ibrahim Girei ${ }^{1}$, Josephine Bosede Ayoola ${ }^{2}$, Godwin A. Abu ${ }^{3}$ \\ ${ }^{1}$ Department of Agricultural Education, Federal College of Education, Yola, Adamawa State, Nigeria
} \\ ${ }^{1,2,3}$ Department of Agricultural Economics, Federal University of Agriculture Makurdi, Benue State, Nigeria.
}

\begin{abstract}
The study examined Socio- economic factors influencing the probability of market participation among the cattle farmers in Adamawa state, Nigeria. Multistage sampling procedure was employed to sample the respondents. Structured questionnaires were used to collect data from 400 respondents in the study area. Descriptive statistic was used to analysed the socioeconomic characteristics of the respondents and logit regression analysis was employed to estimate the determinants market participation among the market participants. The result of the findings shows that cattle market participants were averagely aged 43 years, they are predominantly male (95.04\%), (83.48\%) were married, while (77.96\%), (57.02\%) had formal education and are full-time cattle farmers respectively. the result of logit regression analysis indicates that five variables (gender, education, distance to market, prior market information and seasonality) were significantly found to influence the farmers' decision to participate in the market. The marginal effects were used to interpret the results. Recommendations were made such as to encourage more formal education among the farmers, the more the participant is educated, the better the chance of participation in the cattle market and also to encourage female and those that are unmarried to participate in cattle marketing activities. Provision of reliable market information through mass media or extension services is paramount important in improving market participation and to provide adequate pasture land and water supply so as to curb the problems of exposure to avarice of weather, creates more additional sales point at farming communities is paramount important in the intensity of cattle market participation.
\end{abstract}

Keywords-cattle, factors, farmers, market and participation.

\section{INTRODUCTION}

World agriculture is facing a tremendous challenge due to rapid growth of human population. Global population is estimated to grow annually by 76 million and to exceed 9 billion by the year 2050 (UN, 2009). In developing countries food consumption, in particular animal-product consumption has rapidly increased over the past decades as a result of population and economic growth, higher disposable income and urbanization (Steinfeld et. al., 2006). However, as Nigerian's make up about $50 \%$ of beef consumers in ECOWAS, It is therefore, experiencing a remarkable demographic expansion and a great change in food habits. With a population growth of about $2.8 \%$ per annum, the current domestic production is far from being able to meet up the challenging demand (Bernard et al., 2011).Adesina (2013) lamented that Nigeria will increase the National Dairy Production from its current 469, 000 metric tons to 1.1 million metric tons by attaining an average milk yield per lactating cow from below 500 litres to 2,000 litres per lactation by 2015.Nigeria being the most populous country in West Africa with a population of about 167 million people (National Population Commission, 2012). Moreover, despite the availability of natural resources the country is forced to import more than (25) \% of the beef consumed (Bernard et al. 2010). In developing countries, it's observed that since 1980s the growth of per capita animal-product consumption exceeds that of other groups of food commodities (cereals, roots and tubers) (FAO, 2009). The global production of livestock products (meat, milk and egg) is projected to increase by $50 \%$ by the year 2050 (Steinfeld et. al., 2006). It is observed that one of the most important commodities of livestock subsector is beef cattle, it produce quality meat that has high economic value, and has more important role in public life, important social function in community, therefore it is important to developed the sector and to ensure availability of the product (Prasetyo et. al., 2012).Consequently Markets and improved market access are very essential to rural poor households as a pre-requisite for enhancing agricultural productivity based by improving the competitiveness of farming enterprise, improve the standard of living of rural farmers and to meet up with the challenging global demand by the year 2050. Hence, participation of smallholder farmers in market remains very low due to a range of constraints (Ohenet al., 2013). Market participation among farmers has long been on agricultural economist research programme in both developed and developing countries (Egbetokun and Omonona, 2012). But, still there is a need for more research especially on the area of livestock sector. Marketing in agriculture takes a central role in promoting the future of agricultural business, increased importance and dependence over the past decade on market as the foundation for 
growth strategies put more premiums on understanding market participation among farmers. Moreover, Transformation from subsistence to more specialized and market-oriented systems of agriculture is of significance for a large number of developing countries with a high degree of dependency on agriculture for livelihoods and national income, such a transformation has enormous potential to promote inclusive growth and development, allowing millions of people to escape poverty and food insecurity (Wickramasinghe and Weinberger, 2013). In Somalia livestock are reared and marketed, in 2011, over three million sheep and goats worth over USD 200 million (39.8 billion) were exported to the Middle Eastern countries (mainly Saudi Arabia) (Wanyoike et. al., 2015). However, it is observed that, limited accesses to capital, as well as the difference in livelihood strategies and motivations are the major factors hindering small -scale farmer's participation in the livestock marketing in south-Africa (Ndoro, 2014). Gani and Adeoti (2011) lamented that, in Nigeria Socioeconomic variables such as cooperative membership, family size, high output commercialization ratio and education and supportive infrastructure have been found to be important variables affecting market participation among farmers. Bellemare and Barrett, (2006) also observed that, there has been scant research on market participation especially in developing countries like Nigeria.

\section{Objectives of the study are to;}

1 Find out the socio-economic characteristics of cattle farmers in the study area;

2 Identify the factors influencing market participation among the cattle farmers in the study area;

\section{MATERIALS AND METHODS}

\subsection{Sample and sampling Techniques}

A Multi-stage, random sampling and purposive sampling techniques were employed in the selection of the respondents. In the first stage, two Local Government Areas (LGAs) were purposively selected from each zone of the four zones of Adamawa State Agricultural Development Programme (ADADP), the selection was based on their relative importance in cattle farming.

In the second stage, twenty-six (26) districts were randomly selected from forty five (45) districts of the eight (8) selected LGAs proportionately.

The third stage, involves the random selection of 400 cattle farmers proportionately from the selected districts. Information on the sampling frame was obtained from the Ministry of Livestock Productivity and Nomadic Settlement, Yola. The selection of the four hundred respondents will be based on the proportionality factor presented in equation 1, as adopted from Girohet al. (2012).

$$
S=r / R \times N / 1
$$

Where:

$$
\begin{aligned}
& \mathrm{S}=\text { total number of respondents sampled in each district } \\
& \mathrm{r}=\text { number of cattle farmers in a particular district } \\
& \mathrm{R}=\text { Total number of farmers in all the selected districts } \\
& \mathrm{N}=\text { Sample size }
\end{aligned}
$$

The sample size of 400 cattle farmers with a total population of 6,170 respondents was obtained when use $5 \%$ margin error (confidence interval) and with 95\% confidence level (MarCorr 2014, creative research systems 2012, and Didier 2013). Moreover, the Sample size will also be determined by using Taro Yamane formula as shown below: (Polonia, 2013).

$$
n=\frac{N}{1+N(e)^{2}}
$$

Where: $\mathrm{n}=$ Sample size

$$
\begin{aligned}
& N=\text { Population size } \\
& e=\text { Limit of tolerance error }
\end{aligned}
$$

With a significance level of $95 \%$ the degree of tolerance level will be $5 \%$ (i.e. 0.05 ). 


$$
\begin{aligned}
& n=\frac{6170}{1+6170(.05)^{2}} \\
& n=\frac{6170}{1+6170 * .0025} \\
& n=\frac{6170}{16.425}
\end{aligned}
$$

$\mathrm{n}=376$ to nearest hundred $=400$ Sample size

\subsection{Data analysis techniques}

Descriptive statistics was used to analysed the socioeconomics characteristics of cattle farmers and binary logistic regression analysis was used to analysed socioeconomic factors influencing market participation in the study area.

\subsection{Model Specification}

\subsection{Binary Logistic Regression}

In this study binary logistic model was employed because of its comparable simplicity to probit and to bit regressions. By using the logistic regression the probability of a result being in one of two response groups (binary response) is modelled as a function of the level of one or more explanatory variables.

Thus, the probability whether or not the farmer sells cattle may be modelled as a function of the level of one or more independent variables. For this study, the response variable is 1, when the farmer sells livestock in the past twelve months and .0, when the farmer did not sell. The functional form is denoted in equation (2) (Bahta and Bauer, 2007).

$$
\ln \left(\frac{\emptyset_{i}}{1-\emptyset_{i}}\right)=\beta_{0}+\sum_{j=1}^{k} \beta_{j} X_{i j}+\varepsilon_{i}
$$

Where: $j$ is the response category ( 1 or 0$), i$ denotes cases $(1,2,3,4 ., \mathrm{n}), \emptyset$ is the conditionalprobability, $\beta_{0}$ is the coefficient of the constant term, $\beta_{j}$ is the coefficient of the independent variable, $X_{i j}, \varepsilon_{i}$ is the matrix of unobserved random effects, $\frac{\emptyset_{i}}{1-\emptyset_{i}}$ is "odd", and $\ln \left(\frac{\emptyset_{i}}{1-\emptyset_{i}}\right)$ is the logarithm of "odds".

Equation (2) can be manipulated to give the odds ratio using equation (3):

$$
\frac{\emptyset_{i}}{1-\emptyset_{i}}=\exp \left(\beta_{0}+\sum_{i=1}^{k} \beta_{i} X_{i}\right)
$$

The probability that farm households sell livestock can be calculated using equation (4):

$$
\emptyset_{i}=\frac{\exp \left(\beta_{0}+\sum_{i=1}^{k} \beta_{j} X_{i j}\right)}{1+\exp \left(\beta_{0}+\sum_{i=1}^{k} \beta_{j} X_{i j}\right)}
$$

Equation (4) is intrinsically linear since the logit is linear in $X_{i}$ (Gujarati, 1988); it indicates thatprobability $\emptyset_{i}$ lies between zero and one and vary non-linearly with $X_{i}$. The equation for calculatingpartial effects of continuous variable is denoted by:

$$
\frac{\partial \emptyset_{i}}{\partial x_{i}}=\emptyset_{i}(1-\emptyset) \beta_{j}
$$

The partial effects of the discrete variables will be calculated by taking the difference of the mean probabilities estimated for the respective discrete variable, $X_{i}=0$ and $X_{i}=1$

\section{TABLE 1}

EXOGENOUS VARIABLES IN THE BINARY LOGISTIC REGRESSION MODEL

\begin{tabular}{|c|c|c|c|}
\hline Variable & Description & Measurement & Expected sign \\
\hline Age & Age of the respondents & In years & \pm \\
\hline Gender & Sex of the respondents & $\begin{array}{c}\text { Binary variable (1=male, } \\
\text { 0=female) }\end{array}$ & \pm \\
\hline Education & Level of educational attainment & Number of years spent in school & + \\
\hline Family size & Number of persons in a household & Number & \pm \\
\hline Distance & Distance from home to the market & Kilometers & + \\
\hline Market information & Information about cattle marketing & $\begin{array}{c}\text { Binary variable (1=Access to } \\
\text { information, 0= no access) }\end{array}$ & + \\
\hline Seasonality & Growing season & In time & + \\
\hline
\end{tabular}




\section{RESULT AND DISCUSSIONS}

\subsection{Socio-economic characteristics of the respondents}

Result in Table 2 showed that the cattle market participants were averagely aged 43 years had a family size of average 10 persons, has 19 years' experience in cattle marketing and had average herd size of 49 cattle. They are predominantly male $(95.04 \%)$, married $(83.48, \%)$ while $(77.96 \%)$ of the households had one form of formal education or the other and $(57.02 \%)$ are full-time cattle farmers.

The result shows that $(95.04 \%)$, of the cattle farmers were male. It is how ever male-headed households are more likely to participate in the market as a cattle farming is considered a patriarchal activity. Female-headed households are therefore expected to have lower probability of market participation compared to their male counterparts.

The result in table 2 also indicated that more than $83 \%$ of the sampled respondents were married. It can be inferred that since majority of the respondents were married, they have social obligations to cater for at the household level and this may cause them to take their participation in cattle marketing activities very seriously in order to generate income and to meet their financial obligations.

Education level of the household head could lead to increase in the household's ability to access and utilize market information. From the findings about $78 \%$ of the households had one form of formal education or the other. This implies that they could be able to utilize information more efficiently and consequently improve their managerial skills. This finding conforms to the findings of Randela et. al. (2008) and Enete and Igbokwe (2009) who reported that education provides households with better production and managerial skills which could translate to increased market participation.

\section{TABLE 2}

\section{SOCIOECONOMICS FACTORS OF THE SAMPLED CATTLE FARMERS}

\begin{tabular}{|c|c|c|}
\hline Attribute & Frequency & $\%$ \\
\hline \multicolumn{3}{|l|}{ Age } \\
\hline$<20$ & 12 & 3.31 \\
\hline 20 to 34 & 57 & 15.70 \\
\hline 35 to 49 & 217 & 59.78 \\
\hline $50+$ & 77 & 21.21 \\
\hline \multicolumn{3}{|l|}{ Family size } \\
\hline$<5$ & 56 & 15.43 \\
\hline 5 to 9 & 94 & 25.90 \\
\hline 10 to 14 & 186 & 51.24 \\
\hline $15+$ & 27 & 7.44 \\
\hline \multicolumn{3}{|l|}{ Years of market experience } \\
\hline$<5$ & 21 & 5.79 \\
\hline 5 to 14 & 91 & 25.07 \\
\hline 15 to 24 & 209 & 57.58 \\
\hline $25+$ & 42 & 11.57 \\
\hline \multicolumn{3}{|l|}{ Herd size } \\
\hline$<50$ & 183 & 50.41 \\
\hline $50-99$ & 65 & 17.91 \\
\hline $100-149$ & 68 & 18.73 \\
\hline $150+$ & 47 & 12.95 \\
\hline \multicolumn{3}{|l|}{ Gender } \\
\hline Male & 345 & 95.04 \\
\hline Female & 18 & 4.96 \\
\hline \multicolumn{3}{|l|}{ Marital status } \\
\hline Single & 50 & 13.77 \\
\hline Married & 303 & 83.48 \\
\hline Widowed & 5 & 1.38 \\
\hline Divorced & 5 & 1.38 \\
\hline \multicolumn{3}{|l|}{ Education } \\
\hline No formal education & 80 & 22.04 \\
\hline Adult/Primary Education & 83 & 22.87 \\
\hline Secondary & 108 & 29.75 \\
\hline Post-secondary & 92 & 25.34 \\
\hline \multicolumn{3}{|l|}{ Major occupation } \\
\hline Cattle farming & 207 & 57.02 \\
\hline Civil servant & 92 & 25.34 \\
\hline Trading & 57 & 15.7 \\
\hline Farming & 7 & 1.93 \\
\hline
\end{tabular}




\subsection{Factors influencing cattle market participation}

To determine the factors influencing the probability of participation in the cattle market in Adamawa State, a logit model was estimated. The result presented in Table 3 indicates that five variables (gender, education, distance to market, prior market information and seasonality) were significantly found to influence the farmers' decision to participate in the market. The marginal effects were used to interpret the results.

The result in table 3, reveals that gender of the household head significantly and positively influenced market participation. Being male-headed household increases the probability of participating in the cattle market by $45.71 \%$, all other factors held constant. This suggests that the male headed households are more market oriented than female, hence they participate more in the market. The finding concurs with findings of Onoja et. al. (2012) who reported that the probability of participating in fish marketing was significantly determined by sex of the fish farmer/marketer in Niger Delta Region.

Educational level of the household head significantly and positively influenced market participation. One year increases in household head education, increase the probability of participating in the cattle market by $13.33 \%$, all other factors held constant. This can be explained by the fact that as an individual access more education he/she is empowered with the marketing skill and knowledge that will spur individual to participate in the market, this suggests that higher level of education provides a greater opportunity for the farmers to participate in the cattle market. This is in consistent with Girei and Omonona (2009) who shows that education have positively influenced participation as a net seller in the cattle market in Nigeria. The more the participant is educated, the better the chance of participation in the cattle market. The implication of the results is that education assists in participation in cattle market by providing information on prices and market information systems.

Market distance is negative but significantly related to the probability of participating in the cattle markets. The partial effect of the market distance on the conditional probability for participation is -0.0022 , this implies that each unit increment in the market distance will decrease the probability of participation by 0.0022 . Logically it makes sense since the markets are not readily available in rural areas. Thus, the results suggest that those households which can "reach" the desired marketing distance are more likely to participate mainly due to high producer margin and low variable transaction cost. This is in line with the findings of Uchezuba et al (2009) who indicates that market distance have a negative impact on the probability of the small-scale farmers marketing their animals to formal markets in south Africa.

Market information is negatively and significantly related to the probability of participating in the cattle markets. This implies that the receivers of market information are less likely to sell more cattle than non-receivers. The results indicate that a unit increase in receiving market information has the probability chances of decreases participation in the cattle markets by 0.133. This study is in line with findings Erick et al. (2015) who showed that, access to market information negatively affect market participation, because Market conditions are dynamic and bound to change frequently with regards to price, potential consumers' lifestyle, taste and preference change and government regulations. But contrary to the findings of Apin et. al 2015, Musah et. al., 2014, Ohen et. al 2014, Omiti et. al., 2009, Terfa et. al., 2012, Wanyoike et. al., 2015, and Zamasiya et al., 2014 who reported that access to market information boosts confidence of household who are willing to participate in the market. However, this study may not be unconnected with the fact that most of cattle buyers transport them to southern and eastern part of the country. Therefore, they buy cattle every other week; hence, if a household receives information say on favorable price this week, participation in the market the following week may not replicate same since the availability and the price of cattle in southern and eastern part of the country determined the price in the north.

Seasonality was used as proxy for drought risk. Drought risk was defined as the possibility of a danger which might affect grazing, water and other related resources due to the absence of rainfall (Montshwe, 2006). High drought risk is defined by very low rainfall and the lack of natural grazing which leads to the use of alternative methods of feeding cattle during drought times. It is hypothesized that an increase in risk will lead to increased participation in the cattle markets by smallscale cattle farmers. The result indicated that the variable season was positive and significant at $1 \%$ level. The marginal effect indicated that seasonality increases the probability of participating in cattle markets. 


\section{TABLE 3}

RESULTS OF THE LOGIT REGRESSION ANALYSIS FOR FACTORS INFLUENCING MARKET PROBABILITY OF PARTICIPATION

\begin{tabular}{|c|c|c|c|c|c|}
\hline Variables & $\begin{array}{c}\text { Coefficients } \\
(\mathbf{B})\end{array}$ & $\begin{array}{c}\text { Standard } \\
\text { Error }\end{array}$ & $\mathbf{Z}$ & Significance & Marginal effect \\
\hline Age & 0.006 & 0.014 & 0.43 & 0.656 & 0.0012 \\
\hline Gender & 2.008 & 0.374 & 5.37 & $0.000^{* * *}$ & 0.4571 \\
\hline Education & 0.641 & 0.305 & 2.10 & $0.036^{* *}$ & 0.1333 \\
\hline Family size & 0.003 & 0.023 & 0.13 & 0.898 & 0.0005 \\
\hline Distance to market & 0.011 & 0.007 & -1.74 & $0.083^{*}$ & -0.0022 \\
\hline Prior market information & -0.790 & 0.372 & -2.12 & $0.034^{* *}$ & -0.1331 \\
\hline Season & 0.700 & 0.269 & 2.60 & $0.009^{* * *}$ & 0.1418 \\
\hline Constant & -1.593 & 0.753 & -2.12 & 0.034 & - \\
\hline Chi-square $(\chi 2)$ & $48.75^{* * *}$ & & & & \\
\hline Log likelihood & -191.205 & & & & \\
\hline Number of farmers & 363 & \multicolumn{7}{|l|}{ Source: Field survey, 2016 } & ** Significant at 5\% & Significant at 10\% \\
\hline
\end{tabular}

\subsection{Conclusion}

The following conclusions were drawn from this study:

i. This finding concluded that cattle farmers have good chances of driving market advantage, because majority of farmers are at their productive age.

ii. Those in cattle business were predominantly male, married. Therefore good market participation will help in raising household income.

iii. Since majority of the respondents are literate they can be able to utilize information more efficiently and consequently improve their managerial skills.

iv. Variables like proximity to market and market information decrease farmers' participation in the market while gender, education, and seasonality promote market participation in the area.

v. Inadequate feed is the cause of severe constraint on cattle business in the study area, followed by inadequate water and the least problem is theft. These observed constraints may force the cattle farmers to dispose of their cattle and hence affect the productivity of their business and market commercialization.

\subsection{Policy Recommendations}

The following policy recommendations are made based on the findings from the study:

i. Since majority of the respondents were of moderate age,youths should be encouraged to participate in marketing activities to expand the current marketing system and to address the challenges facing agriculture in term of food insecurity and revenue generation.

ii. Cattle-marketing is male-dominated. Therefore, there is need to encourage women to participate actively in the cattle market; and also, the unmarried should be encouraged to participate as most of the participants are married.

iii. Since market information has positively influenced the probability of participation in the cattle market. Therefore, provision of reliable market information through mass media or extension services is of paramount importance in improving market participation in the study area.

iv. The study also recommends that efforts should be made to upgrade road networks in the study area so as to reduce the transaction cost and encourage cattle market participation. 
v. Since the major problems encountered by cattle farmers were inadequate feed and water during dry season and problem of insecurity, there is need to provide adequate pasture land, water supply and security for the cattle farmers so as to curb the problems of theft, pilfering as well as exposure to adverse weather.

\section{REFERENCES}

[1] Adebayo, A. A. and Tukur, A.L. (1999).Adamawa State in Maps. Paraclete Publishing House, Yola - Nigeria.pp. 1-4.

[2] Adesina, A. (2013). National Diary Production. Federal Ministry of Agriculture and Rural Development. Available on: http://www.fmard.gov.ng/national-dairy-production Assessed on 21, june, 2015.

[3] Apin, B. O., Lagat, J. K., Bett, H. K. and Kirui, J. K. (2015).Determinants of Small-holder Farmers Extent of Market Participation; Case of Rice Marketing in Ahero Irrigation Scheme, Kenya. Journal of Economics and Sustainable Development. 6(2): 154.Available on: www.iiste.org. Assessed on $6^{\text {th }}$,nov, 2015.

[4] Bahta, S.T. and Bauer, S. (2007). Anlysis of the Determinants of Market Participation within the South African Small-scale Livestock Sector,. Paper presented at Tropentag. October 9-11, 2007.Theme: witzenhausen: Utilisation of diversity in land use systems: Sustainable and organic approaches to meet human needs. 422 (1); 1-8. Available on: http://www.tropentag.de/2007/abstracts/full/422.pdf. Assessed on: $27^{\text {th }}$ nov, 2015.

[5] Bellemare, M. F., andBarrett, C. B. (2006). "An ordered Tobit model of market participation" Evidence from Kenya and Ethiopia. American Journal of Agricultural Economics. 88 (2), pp328-334.

[6] Benard, C.,Bennet, B. and Gulbert B. (2010).Demand for Farm Animal products in Nigeria : an opportunity for sahel countries. Ministry of livestock and animal resources, funded by the european union. Special document. Available on www.inter-reseaux.org/img/pdf/p14-15_animal.pdf. Assessed on $9^{\text {th }}$, feb, 2015.

[7] Creative Research Systems. (2012).Sample size Calculator. Available on: https//www.surveysystem.com. Assessed on: $11^{\text {th }}$,oct. 2014.

[8] Didier, D. (2013). How to Estimate your Population and Survey Sample size. https//www.checkmarket.com.Assessed on $12^{\text {th }}$, oct. 2014.

[9] Egbetokun, O.A. and Omonona B.T. (2012).Determinants of Farmers' Participation in Food Market, Global Journal of Science Frontier Research Agriculture and Veterinary Sciences.12 (9), Publisher: Inc (USA). 24-30. Available on: https://globaljournals.org/GJSFR_Volume12/3-Determinants-of-Farmers..Assessed on 10 ${ }^{\text {th }}$, oct. 2014.

[10] Enete A. A, Igbokwe E. M. (2009). Cassava Market Participation Decisions of Producing Households in Africa. Tropicultura 27(3):129-136.

[11] FAO, (2009).The State of Food and Agriculture -Livestock in the Balance. Food and Agriculture Organization Rome, Italy,180pp. Available on: http://www.fao.org/docrep/012/i0680e/i0680e00.htm. Assessed on 2 ${ }^{\text {nd }}$, January, 2015.

[12] Gani, B.S. and Adeoti,.A.I. (2011). Analysis of Market Participation and Rural Poverty among Farmers in Northern Part of Taraba State, Nigeria, Journal of Economics Kamla-raj, New Delhi, India. 2(1): 23-36. Available on: http://www.krepublishers.com/02Journals. Assessed on: $8^{\text {th }}$, march, 2015.

[13] Girei,.M.I. and Omonona B.T. (2009).Estimation of determinants of Market participation among cattle farmers in Adamawa state, journal of Agricultural Science and Natural Resources. 2 (1): 9-12. Rosefet Academic Publishers

[14] Giroh, D. Y., Adebayo, E. F., and Jongur, A. A. U. (2014). Efficiency of Latex Production in Rubber Plantations in Edo and Delta States, Nigeria. American Journal of Research Communication www. usa-journals. com, http://www. usa-journals.com/wpcontent/uploads/2012/11/Giroh. pdf. Assessed on: $10^{\text {th }}$, may, 2015

[15] MaCorr (2014), Sample Size Methodology, https//www.macorr.com/sample size-calculator.htm. Assessed on $10^{\text {th }}$, Aug. 2014.

[16] Mohammed, K. (1999).Historical Background of Adamawa State. In: Mohammed, B. \&

[17] Sahabo, M. ed(s). A compendium of Studies and Issues in Pastoralism in Nigeria Paraclete publishers Yola - Nigeria.

[18] Montshwe, B., D. (2006). Factors affecting participation in mainstream cattle markets by small Scale cattle farmers in South Africa, M.Sc. project report. Department of Agricultural Economics Faculty of Natural and Agricultural Sciences University of Free State, Bloemfontein. Pp135. Available online at http://etd.uovs.ac.za/ETD- db//theses/available etd. Assessed on: 23 ${ }^{\text {rd }}$, april, 2015.

[19] Musah, A. B., Bonsu O. Y. and Seini W. (2014). Market Participation of Small holder Maize Farmers in the Upper West Region of Ghana.African journal of Agricultural Research. 9(31):2427. Available on: http//www.academicjournals.org./AJAIL. Assessed on: $6^{\text {th }}$, nov, 2015.

[20] Ndoro, T. j,.Mudhara, M., and Chimony, M. (2014) Cattle Commercialization in Rural South Africa: Livelihood Drivers and Implications for Livestock Marketing extension.J Hum Ecol. 45(3): 207. Available on www.krepublishers.com/. Assessed date 27 ${ }^{\text {th }}$, july 2015.

[21] NPC. (2012). National Population Commission. http//www.channelstv.com/2012/08/05/there-are-167-million-people-in-nigeria-npc/

[22] Ohen, S.B., Umeze,G. E., and Cobham, M. E. (2014). Determinants of Market Participation by Cucumber Farmers in Odukpani Local Government Area, Cross River State, Nigeria. Journal of Economics and Sustainable Development. 5 (2):188. Available on: www.iiste.org. assessed on: $7^{\text {th }}$, nov, 2015.

[23] Omiti, M. J., Otieno D. J,,Nyanamba T. O. andMccullough, E. (2009).Factors influencing The Intensity of Market Participation by Smallholder Farmers: A case study of rural and peri-urban areas of Kenya. Afjare journal.3 (1): 57 . Available on: http://ageconsearch.umn.edu/bitstream/56958/2/0301Omiti\%20-\%20FINAL.pdf. Assessed on: 20th, dec, 2015.

[24] Onoja, A. O.,Usoroh, B. B.,Adieme D. T. and Deedam, N.J.( 2012). Determinants of Market Participation in Nigerian Small- Scale Fishery Sector: Evidence from Niger Delta Region.The Journal of Sustainable Development 9 (1); 69 - 84. 
[25] Polonia, G.F.T.(2013), Analysis of Sample Size in Consumer Surveys. GFK Poland. Pp 6-9. Available on: ec.europa.eu/.../surveys/.../pl-gfk_k._pusczak. Assessed on: $15^{\text {th }}$,nov. 2014.

[26] Prasetyo, E.,Sunarso, S. P., Rianto, E., Ekowati, T. Yuwana, D. and Mulyatno, B. ( 2012). The Influence of 5-C factors on rate of credit return in beef cattle farming in central java, Journal Of The Indonesian Tropical Animal Agriculture, 37( 3): pp. $213-219$.

[27] Randela R, Alemu, Z. G., and Groenewald, J. A. (2008). Factors enhancing market participation by small-scale cotton farmers, Agrekon: Agricultural Economics Research Policy Pract. S. Afr. 47(4):451-469

[28] Sajo, A.A. and Kadams, A.M. (1999). Food and cash crops in: Adamawa State in Maps Adebayo, A.A. and Tukur, A.L. (eds).P.44.Paraclete publishers Yola - Nigeria.

[29] Steinfeld, H., Gerber P., Wassenear T., Castel V., Rosales M.,Dehaam, C., (2006). livestock's long shadow:Enviromental issues and options. Food and Agriculture Organization Rome,Italy, 390p.

[30] Tukur, A.L., and Ardo, M.B. (1999). Livestock in Adamawa in: Adebayo, A.A. and Tukur, A.L. (ed) Adamawa State in Maps. Paraclete publishers Yola.

[31] Uchezuba, I.D.,Moshabele, E., and Digopo, D. (2009). Logistical Estimation of the Probability of Mainstream Market Participation among small-scale livestock farmers: a case study of The Northern Cape province. journal of Agrekon,48,(2):171-183

[32] UN, (2009) .World Population Prospects.2008 Revision. Available on: http/www.un.org/population/publication/wpp 2008 highlights.

[33] Wanyoike,F., Mtimet, N., Ndiwa, N., Marshall, K., Godiah, L. and Warsame, A. (2015). Knowledge of Livestock Grading and Market Participation among Small Ruminant Producers in Northern Somalia. East African Agricultural and Forestry Journal, 81: 64-70. Available on: http://dx.doi.org/. assessed on $14^{\text {th }}$, nov, 2015.

[34] Wickramasinghe, U., and Weinberger, K. (2013).Smallholder Market Participation and Production Specialization, (CAPSA). Working paper No. 107.Bogor, Indonesia. 35pp. Available on: www.uncapsa.org/publication/WP107.pdf. Assessed on: 11 ${ }^{\text {th }}$, may, 2015.

[35] Zamasiya, B., Mango, N., Nyikahadzoi, K. and Siziba, S. (20 14). Determinants of Soybean Market Participation by Small holder Farmers in Zimbabwe. Journal of Development and Agricultural Economics.6(2): 49. Available on: http/www.academicjournals.org. assessed on $16^{\text {th }}$,nov,2015. 